\title{
Nastolatek traci przytomność na ulicy
}

\author{
Teenager lost consciousness in the street
}

\author{
Sebastian Ciemny ${ }^{1}$, Joanna Kwiatkowska ${ }^{1}$, Tomasz Królak², Maciej Kempa ${ }^{2}$ \\ ${ }^{1}$ Katedra i Klinika Kardiologii Dziecięcej i Wad Wrodzonych Serca Uniwersyteckiego Centrum Klinicznego w Gdańsku \\ ${ }^{2}$ Klinika Kardiologii i Elektroterapii Serca Gdańskiego Uniwersytetu Medycznego
}

\section{Streszczenie}

Piętnastoletni chłopiec upadł na ulicy. Świadkowie wezwali pogotowie ratunkowe i podjęli czynności resuscytacyjne. Przybyły na miejsce zespół pogotowia ratunkowego rozpoznał zatrzymanie krążenia w mechanizmie migotania komór (VF). Po wykonaniu trzech defibrylacji oraz podaniu adrenaliny dożylnie uzyskano powrót rytmu zatokowego i przetransportowano chłopca na oddział intensywnej terapii. Wykonano koronarografię, w której nie stwierdzono zmian w naczyniach wieńcowych. Z powodu niewydolności oddechowej pacjent wymagał 12-dniowej respiratoroterapii. W celu rozszerzenia diagnostyki oraz kwalifikacji do dalszego leczenia pacjenta przewieziono do Kliniki Kardiologii Dziecięcej i Wad Wrodzonych Serca UCK w Gdańsku. Według danych z dokumentacji medycznej chłopiec od wczesnego dzieciństwa pozostawał pod opieką poradni kardiologicznej dla dzieci z powodu rozpoznanej w okresie noworodkowym anomalii Ebsteina. W celu poszukiwania uleczalnych przyczyn zatrzymania krążenia zakwalifikowano go do badania elektrofizjologicznego. W badaniu tym nie wykazano obecności dodatkowej drogi przewodzenia przedsionkowo-komorowego i wyindukowano nieutrwalony częstoskurcz komorowy złożony z 13 pobudzeń. Z powodu braku stwierdzonej możliwej do leczenia przyczyny VF pacjentowi implantowano kardiowerter-defibrylator w ramach prewencji wtórnej nagłego zatrzymania krążenia.

Słowa kluczowe: omdlenia, nagłe zatrzymanie krążenia, dzieci

Folia Cardiologica 2016; 11, 1: 61-65

\section{Wstęp}

Migotanie komór (VF, ventricular fibrillation) jest rzadką przyczyną nagłego zatrzymania krążenia (SCA, sudden cardiac arrest) u pacjentów w grupie wiekowej 0.-18. roku życia. Częstość występowania pierwotnego VF u dzieci wynosi 3,8-19\% przypadków SCA [1-8] i wzrasta z wiekiem $[9,10]$. Pacjenci z wrodzoną wadą serca są grupą bardziej narażoną na występowanie zaburzeń rytmu. Stwierdzenie VF jest bardziej prawdopodobne u dzieci lub nastolatków z chorobą serca, u których doszło do nagłej utraty przytomności [2-4]. Część przyczyn mogących leżeć u podłoża wystąpienia VF można rozpoznać i skutecznie leczyć. Inne niemożliwe do wykrycia lub niepodlegające leczeniu pozwalają zakwalifikować pacjenta do implantacji kardiowertera-defibrylatora (ICD, implantable cardioverter-defibrillator) w ramach wtórnej prewencji SCA.

\section{Opis przypadku}

Piętnastoletni chłopiec wracał do domu. W pewnej chwili jego chód stał się chwiejny, po czym chłopiec nagle upadł. Część świadków chciała go pozostawić bez pomocy, twierdząc, że jest pijany. Szczęśliwie pozostali świadkowie

Adres do korespondencji: lek. Sebastian Ciemny, Katedra i Klinika Kardiologii Dziecięcej i Wad Wrodzonych Serca, Uniwersyteckie Centrum Kliniczne, ul. Dębinki 7, budynek 3, 80-211, Gdańsk, tel. 5834928 97/57, e-mail: s_e.b_a@gumed.edu.pl 


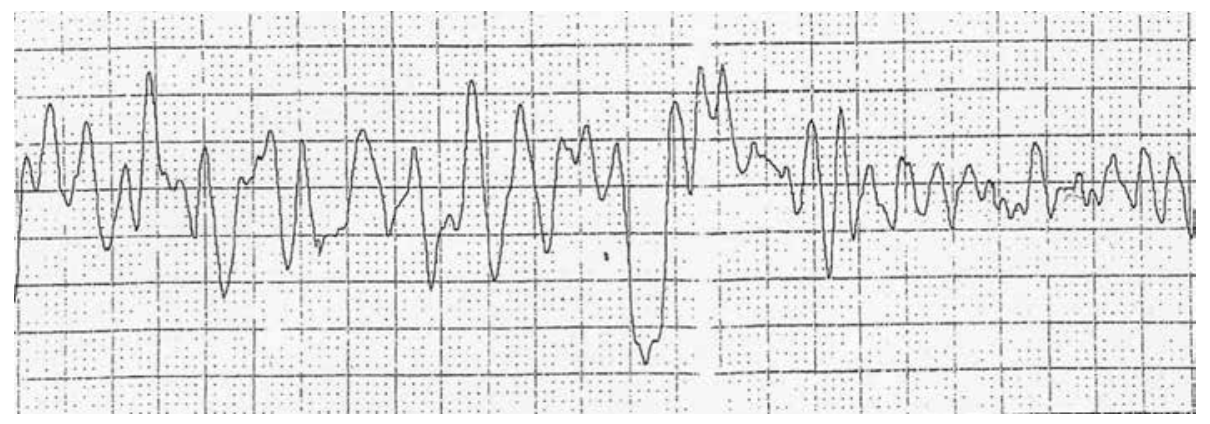

Rycina 1. Zapis z monitora podczas zatrzymania krążenia (materiał własny)

zdarzenia zareagowali i starali się udzielić pomocy potrzebującemu. Po nieudanej próbie nawiązania kontaktu stwierdzili, że nie oddycha. Natychmiast zadzwonili na numer alarmowy i zgłosili zaistniałe zdarzenie, a następnie przystąpili do czynności resuscytacyjnych. Po kilku minutach przybyło pogotowie ratunkowe, którego zespół przejął pacjenta od świadków zdarzenia i kontynuował masaż serca, równocześnie podłączając defibrylator. Na monitorze urządzenia udało się uzyskać następujący zapis (ryc. 1).

$\mathrm{Na}$ tej podstawie rozpoznano VF. Po zastosowaniu wentylacji mechanicznej, 3-krotnej defibrylacji oraz podaniu adrenaliny dożylnie udało się uzyskać powrót rytmu zatokowego. Od utraty przytomności do powrotu rytmu zatokowego minęło około 30 minut. Stan chłopca był ciężki. Pacjenta przetransportowano do szpitala, w którym natychmiast wykonano badanie koronarograficzne. W badaniu tym nie wykazano zmian w naczyniach wieńcowych. Chłopca przekazano na oddział intensywnej opieki medycznej (OIOM), gdzie z powodu niewydolności oddechowej wymagał respiratoroterapii przez 12 dni. W wywiadzie od rodziny uzyskano informacje, że od okresu noworodkowego chłopiec pozostaje pod opieką poradni kardiologicznej dla dzieci z powodu rozpoznanej anomalii Ebsteina. Poza tym w okresie kilku dni przed wystąpieniem SCA występowały u niego objawy infekcji kataralnej. Na podstawie wykonanego badania radiologicznego (RTG) klatki piersiowej rozpoznano zapalenie płuc. Włączono antybiotykoterapię. Z powodu występujących okresowo drgawek po konsultacji neurologicznej włączono kwas walproinowy i piracetam. Od momentu przyjęcia na OIOM podawano dożylnie lek beta-adrenolityczny. Zaburzenia rytmu serca nie nawracały. W wyniku zastosowanego leczenia stan chłopca się poprawił, co umożliwiło kontynuację diagnostyki i leczenia na oddziale pediatrycznym. W tym czasie pacjent był pobudzony, niechodzący. Nawiązywał kontakt wzrokowy z otoczeniem, rozpoznawał rodzinę i spełniał polecenia w ograniczonym zakresie. Rozpoczęto intensywną rehabilitację i ponownie poproszono o konsultację neurologiczną. $\mathrm{Na}$ jej podstawie, po wykonaniu badania metodą tomografii komputerowej głowy i badania elektroencefalograficznego, zalecono stopniowe odstawienie kwasu walproinowego. Uzyskano poprawę w zakresie sprawności intelektualnej i motorycznej. Po 39 dniach hospitalizacji od wystąpienia SCA pacjenta przewieziono do Klinika Kardiologii Dziecięcej i Wad Wrodzonych Serca Uniwersyteckiego Centrum Klinicznego w Gdańsku w celu pogłębienia diagnostyki i ewentualnego dalszego leczenia.

Przy przyjęciu do kliniki nastolatek był w dobrym stanie ogólnym, z ograniczonym w niewielkim stopniu kontaktem logicznym; spełniał polecenia, chodził i rozmawiał. W opinii rodziny największy problem stanowią zaburzenia pamięci. Według informacji uzyskanych z wywiadu od około roku okresowo zdarzały się napady szybkiego miarowego bicia serca trwające do kilku minut, bez pogorszenia samopoczucia, ustępujące samoistnie. W wykonywanym okresowo w ramach opieki poradni kardiologicznej dla dzieci badaniu elektrokardiograficznym (EKG) metodą Holtera nie zarejestrowano istotnych odchyleń od normy. W przeprowadzonym w klinice badaniu echokardiograficznym potwierdzono cechy anomalii Ebsteina, tj. przemieszczenie dokoniuszkowe płatków przegrodowego i tylnego zastawki trójdzielnej o około 43 mm w stosunku do zastawki mitralnej (ryc. 2), masywną i wielostrumieniową falę niedomykalności zastawki trójdzielnej oraz znacznie poszerzony prawy przedsionek (RA, right atrial) (powierzchnia RA $=62 \mathrm{~cm}^{2}$ ) z dobrą kurczliwością lewej i prawej komory.

W wykonanym w klinice badaniu EKG oraz EKG metodą Holtera zapisy bez jawnych cech preekscytacji, zarejestrowano skłonność do bradykardii zatokowej, liczne okresy niemiarowości zatokowej, bez pauz RR i bez zaburzeń rytmu, ze stałym blokiem prawej odnogi pęczka Hisa (RBBB, right bundle branch block). Chłopca zakwalifikowano do badania elektrofizjologicznego, by ustalić podłoże zaburzeń rytmu. W znieczuleniu ogólnym poprzez żyłę udową wprowadzono cewniki diagnostyczne. Wyjściowo rytm zatokowy bez cech preekscytacji. W trakcie stymulacji przedsionków nie indukowano arytmii. W trakcie stymulacji komór brak przewodzenia komorowo-przedsionkowego. Nie indukowano 


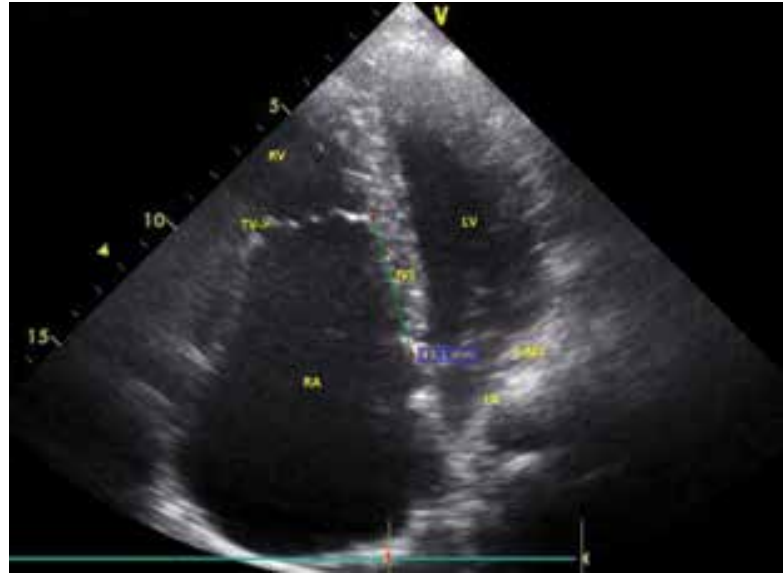

Rycina 2. Obraz uzyskany w badaniu echokardiograficznym (materiał własny); RV (right ventricle) - prawa komora; LV (left ventricle) - lewa komora; RA (right atrial) - prawy przedsionek; LA (left atrial) - lewy przedsionek; TV (tricuspid valve) - zastawka trójdzielna; MV (mitral valve) - zastawka mitralna

utrwalonych tachyarytmii komorowych. Obserwowano jedynie jednokrotny nieutrwalony częstoskurcz komorowy (nsVT, nonsustained ventricular tachycardia) złożony z 13 pobudzeń. Wykluczono obecność dodatkowej drogi przewodzenia przedsionkowo-komorowego. Na tej podstawie z powodu braku stwierdzonej, możliwej do leczenia przyczyny wystąpienia VF pacjent został zakwalifikowany do implantacji kardiowertera defibrylatora celem prewencji wtórnej nagłego zatrzymania krążenia w mechanizmie VF (ryc. 3) Około 6 miesięcy od implantacji ICD chłopiec ponownie został przyjęty do kliniki z powodu adekwatnego wyładowania urządzenia z powodu częstoskurczu komorowego (VT, ventricular tachycardia).

\section{Omówienie}

Zgodnie z art. $162 \S 1$ kodeksu karnego „Kto człowiekowi znajdującemu się w położeniu grożącym bezpośrednim niebezpieczeństwem utraty życia albo ciężkiego uszczerbku na zdrowiu nie udziela pomocy, mogąc jej udzielić bez narażenia siebie lub innej osoby na niebezpieczeństwo utraty życia lub ciężkiego uszczerbku na zdrowiu, podlega karze pozbawienia wolności do lat 3". Ustawodawca dodatkowo w szczególny sposób podkreśla obowiązek niesienia pomocy przez lekarza. W art. 30. ustawy o zawodach lekarza i lekarza dentysty napisano: „Lekarz ma obowiązek udzielać pomocy lekarskiej w każdym przypadku, gdy zwłoka w jej udzieleniu mogłaby spowodować niebezpieczeństwo utraty życia, ciężkiego uszkodzenia ciała lub ciężkiego rozstroju zdrowia oraz w innych przypadkach niecierpiących zwłoki". Jednak, by pomoc udzielana przez świadka zdarzenia była skuteczna, konieczna

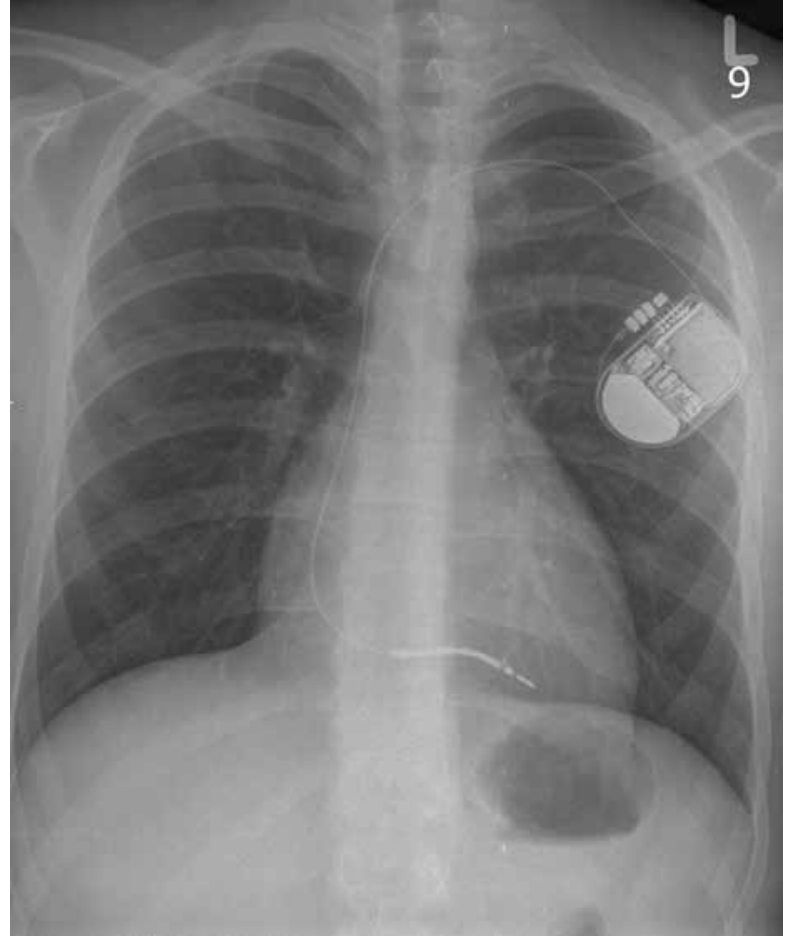

Rycina 3. Kontrolne badanie radiologiczne po implantacji kardiowertera-defibrylatora (materiał własny)

jest znajomość podstawowych zabiegów resuscytacyjnych (BLS, basic life support). Ostatnie wytyczne Polskiej Rady Resuscytacji pochodzą z 2010 roku [11]. Jest w nich mowa o dwóch podstawowych algorytmach BLS zależnie od tego, czy ma się do czynienia z osobą dorosłą czy z dzieckiem. W odniesieniu do osoby dorosłej w wytycznych podkreśla się wage jak najszybszego wezwania wykwalifikowanej pomocy po stwierdzeniu, że poszkodowany nie oddycha. Wynika to z faktu, że w przypadku osób dorosłych większość SCA następuje z przyczyn kardiologicznych i bez dostępu do defibrylatora nie jest możliwa skuteczna pomoc. Po wezwaniu pomocy do czasu przybycia wykwalifikowanych służb powinno się wykonywać uciśnięcia klatki piersiowej i wentylację w sekwencji 30:2. Celem powinno być osiągnięcie głębokości przynajmniej $5 \mathrm{~cm}$ i częstości przynajmniej 100 uciśnięć/min. W wytycznych dopuszczono odstąpienie od prowadzenia wentylacji i ograniczenie się jedynie do masażu klatki piersiowej. W przypadku dzieci dopuszcza się zastosowanie algorytmu dla osób dorosłych ze względu na jego szerszą znajomość i fakt, że rokowanie jest gorsze, jeśli nie zrobi się nic. Według algorytmu podstawowych zabiegów resuscytacyjnych u dzieci dla osób z obowiązkiem interwencji konieczne jest wykonanie 5 oddechów ratowniczych przed rozpoczęciem uciskania klatki piersiowej, a następnie prowadzenie przez około minutę resuscytacji krążeniowo-oddechowej przed 
wezwaniem pomocy. Wynika to z faktu, że większość SCA w grupie dzieci i młodzieży ma charakter wtórny do przyczyn oddechowych. Jedynym wyjątkiem, gdy nie należy prowadzić resuscytacji krążeniowo-oddechowej przez minutę przed wezwaniem pomocy, jest przypadek, w którym dziecko nagle straci przytomność. W tej sytuacji najbardziej prawdopodobną przyczyną zatrzymania krążenia są zaburzenia rytmu serca i dziecko wymaga defibrylacji. Ratowników bez wykształcenia medycznego należy instruować, aby wykonywali 30 uciśnięć klatki piersiowej i 2 oddechy ratownicze, czyli tak samo, jak w wytycznych dla dorosłych, co umożliwia każdemu przeszkolonemu w zakresie BLS prowadzenie resuscytacji dzieci przy znajomości minimum dodatkowych informacji. Ratownicy mający zawodowy obowiązek udzielania pomocy powinni się uczyć i stosować sekwencję 15:2, jednak może to być sekwencja 30:2, jeśli działają w pojedynkę, szczególnie gdy nie udaje się im osiągnąć wystarczającej liczby uciśnięć.

Anomalię Ebsteina po raz pierwszy opisał w 1866 roku pracujący we Wrocławiu niemiecki lekarz Wilhelm Ebstein. Określenie „zespół Ebsteina” zasugerował w 1927 roku Arnstein, a następnie po upływie 10 lat Yater i Shapiro opisali 16 przypadków tej wrodzonej wady serca. Do roku 1951 wszystkich rozpoznań dokonywano post mortem. Po raz pierwszy przyżyciowo diagnozy dokonano na podstawie cewnikowania serca w tymże roku. Pierwsze próby leczenia polegały na zastosowaniu zespolenia Blalock-Taussig (połączenie tętnicy podobojczykowej z tętnicą płucną) oraz zespolenia Glenna (połączenie żyły głównej górnej z prawą tętnicą płucną). W 1962 Barnard i Schrire zastosowali w leczeniu sztuczną zastawkę. W 1964 roku po raz pierwszy Hardy wykonał udaną plastykę zastawki trójdzielnej w tej wadzie $[12,13]$.

Anomalia Ebsteina jest rzadką wrodzoną wadą serca występującą z częstością 1-5/200 000 żywo urodzonych noworodków. Stanowi około 0,5\% wrodzonych wad serca $[14,15]$. Polega na zniekształceniu płatków przegrodowego i tylnego zastawki trójdzielnej i przemieszczeniu ich przyczepów w kierunku jamy prawej komory. Powoduje to przesunięcie zastawki w kierunku koniuszka [12]. Wada ta charakteryzuje się bardzo zróżnicowanym stopniem zaawansowania klinicznego - od postaci łagodnych do bardzo ciężkich. Przemieszczenie płatków powoduje podzielenie prawej komory na dwie części. Tak zwana za- trializowana część komory znajduje się między miejscem prawidłowego pierścienia zastawkowego a linią nieprawidłowo umocowanych płatków. Anatomicznie należy ona do komory prawej, a czynnościowo jest częścią znacznie powiększonego prawego przedsionka. Pozostała część komory tworzy właściwą komorę, czasem bardzo małą, którą mogą stanowić tylko koniuszek i droga odpływu prawej komory [16]. U 5-10\% pacjentów występuje dodatkowa droga przewodzenia przedsionkowo-komorowego, co może się stać podłożem wystąpienia zespołu preekscytacji [16]. Dla porównania obecność dodatkowej drogi przewodzenia przedsionkowo-komorowego stwierdza się u 0,1-0,3\% populacji ogólnej [17, 18]. W przypadku anomalii Ebsteina jest to anatomiczne mięśniowe połączenie komory z przedsionkiem, zwykle w obszarze brakującego fragmentu pierścienia zastawki trójdzielnej. U chorych, u których występuje zespół Wolffa-Parkinsona-White'a (WPW) pierwszym objawem może być VF i istnieje zwiększone ryzyko SCA, które szacuje się na 0,02-0,15\%/rok [19, 20]. Najczęstszą przyczyną SCA w zespole WPW jest degeneracja migotania przedsionków do VF. Zabieg przezskórnej ablacji szlaku dodatkowego to metoda z wyboru u chorych obciążonych zwiększonym ryzykiem występowania zaburzeń rytmu na podłożu drogi dodatkowej. 0 ile w ogólnej populacji skuteczność tej metody jest wysoka (> 95\% w szlakach lewostronnych, 90-95\% w szlakach prawostronnych), o tyle w zespole Ebsteina jest niższa i wynosi 76-82\% [21].

Profilaktyka wtórna SCA dotyczy chorych, u których doszło do zatrzymania krążenia w mechanizmie VF/VT bądź wystąpił istotny hemodynamicznie VT, i polega na zabezpieczeniu chorego poprzez wszczepienia ICD. Idiopatyczne migotanie komór (IVF, idiopathic ventricular fibrillation), bez możliwej do zidentyfikowania przyczyny, stanowi do 10\% przypadków nagłych zgonów wśród osób młodych [22].

Nie zaleca się implantacji ICD u osób po zatrzymaniu krążenia, do którego doszło w wyniku znanych i odwracalnych przyczyn lub kiedy istnieje możliwość skutecznego leczenia przyczynowego, na przykład w zespole WPW, w przebiegu którego właściwym postępowaniem jest zabieg ablacji [23].

\section{Konflikt interesów}

Autorzy deklarują brak konfliktu interesów. 


\section{Abstract}

A 15-year-old boy fell down unconscious in the street. Witnesses called an ambulance and have started resuscitation. The rescue team arrived in a few minutes and diagnosis of cardiac arrest in the course of ventricular fibrillation was established. After third defibrillation and administration of adrenaline intravenously, sinus rhythm returned and the patient was transported to the hospital to the intensive care unit. The coronary angiography revealed no anomalies in the coronary arteries. He needed 12-day respiratory therapy due to respiratory failure. Afterwards he was transferred to the Department of Paediatric Cardiology and Congenital Heart Defects for further diagnostics and treatment evaluation. According to the medical records he has been under the cardiological care since early childhood due to the diagnosis of Ebstein anomaly. Looking for a treatable cause of cardiac arrest invasive electrophysiological study (EPS) was performed. The study did not reveal any accessory atrioventricular pathway and during the study non-sustained ventricular tachycardia consisting of 13 beats was triggered. Due to the lack of treatable causes of ventricular fibrillation the patient received cardioverter-defibrillator as a secondary prevention of sudden cardiac arrest.

Key words: fainting, cardiac arrest, children

Folia Cardiologica 2016; 11, 1: 61-65

\section{Piśmiennictwo}

1. Tibballs J., Carter B., Kiraly N.J. i wsp. External and internal biphasic direct current shock doses for pediatric ventricular fibrillation and pulseless ventricular tachycardia. Pediatr. Crit. Care Med. 2011; 12: 14-20.

2. Atkins D.L., Everson-Stewart S., Sears G.K. i wsp. epidemiology and outcomes from out-of-hospital cardiac arrest in children: the resuscitation outcomes consortium epistry-cardiac arrest. Circulation 2009; 119: 1484-1491.

3. Rodriguez-Nunez A., Lopez-Herce J., Garcia C. i wsp. Pediatric defibrillation after cardiac arrest: initial response and outcome. Crit. Care 2006; 10: R113.

4. Samson R.A., Nadkarni V.M., Meaney P.A. i wsp. Out-comes of in-hospital ventricular fibrillation in children. N. Engl. J. Med. 2006; 354: 2328-2339.

5. Reis A.G., Nadkarni V., Perondi M.B. i wsp. A prospective investigation into the epidemiology of in-hospital pediatric cardiopulmonary resuscitation using the international Utstein reporting style. Pediatrics 2002; 109: 200-209.

6. Mogayzel C., Quan L., Graves J.R. i wsp. Out-of-hospital ventricular fibrillation in children and adolescents: causes and outcomes. Ann. Emerg. Med. 1995; 25: 484-491.

7. Herlitz J., Engdahl J., Svensson L. i wsp. Characteristics and outcome among children suffering from out of hospital cardiac arrest in Sweden. Resuscitation 2005; 64: 37-40.

8. Kuisma M., Suominen P., Korpela R. Paediatric out-of-hospital cardiac arrests: epidemiology and outcome. Resuscitation 1995; 30 : 141-150.

9. Atkins D.L., Hartley L.L., York D.K. Accurate recognition and effective treatment of ventricular fibrillation by automated external defibrillators in adolescents. Pediatrics 1998; 101: 393-397.

10. Appleton G.O., Cummins R.O., Larson M.P. i wsp. CPR and the single rescuer: at what age should you "call first" rather than "call fast"? Ann. Emerg. Med. 1995; 25: 492-494.

11. Jerry P.N., Jasmeet S., David A.Z. i wsp. European Resuscitation Council Guidelines for Resuscitation 2010 Section 1. Executive summary.
Group: Podsumowanie Komitetu Wykonawczego ERC. Polska Rada Resuscytacji, Kraków 2010: 1-73.

12. Kubicka K., Kawalec W. Kardiologia okresu noworodkowego. PZWL, Warszawa 1998.

13. Kirklin J.W., Barratt-Boyes B.G. Cardiac surgery. Churchill Livingstone Inc., New York 1993: 1105-1130.

14. Paron S, Acar P. Ebstein's anomalny of the tricuspid valve : from fetus to adult. Heart 2008; 94: 237-243.

15. Sharland G., Chita S., Allan L.D. Tricuspid valve dysplasia or displacement in intrauterine life. J. Am. Coll. Cardiol. 1991; 17: 944-949.

16. Wronecki K., Mieczyński M., Skalski J.H. Anomalia (zespół) Ebsteina. W: Skalski J., Religa Z. (red.). Kardiochirurgia dziecięca. Tom 2. Wydawnictwo Naukowe Śląsk, Katowice 2003: 351-360.

17. Szczeklik A. Choroby wewnętrzne. Tom I. Medycyna Praktyczna, Kraków 2005: 190.

18. Rosner MH., Brady W.J. Jr, Kefer MP. i wsp. Electrocardiography in the patient with the Wolff-Parkinson-White syndrome: diagnostic and initial therapeutic issues. Am. J. Emerg. Med. 1999; 17: 705-714.

19. Fitzsimmons P.J., McWhirter P.D., Peterson D.W. i wsp. The natural history of Wolff-Parkinson-White syndrome in 228 military aviators: a long-term follow-up of 22 years. Am. Heart J. 2001; 142: 530-536.

20. Munger T.M., Packer D.L., Hammill S.C. i wsp. A population study of the natural history of Wolff-Parkinson-White syndrome in Olmsted County, Minnesota, 1953-1989. Circulation 199; 87: 866-873.

21. Cappato R., Schluter M., Weis C. i wsp. Radiofrequency current catheter ablation of accessory atrioventricular pathways in Ebstein's anomaly. Circulation 1996; 94: 376-383.

22. Brugada J., Blom N., Sarquella-Brugada G. i wsp. Pharmacological and non-pharmacological therapy for arrhythmias in the pediatric population: EHRA and AEPC-Arrhythmia Working Group joint consensus statement. Europace 2013; 15: 1337-1382.

23. Zipes D.P., Camm A.J., Borggrefe M. i wsp. ACC/AHA/ESC 2006 guidelines for management of patients with ventricular arrhythmias and the prevention of sudden cardiac death - executive summary. Eur. Heart J. 2006; 27: 2099-2140. 